\title{
TEACHERS' PERCEPTIONS OF \\ CULTURALLY APPROPRIATE PEDAGOGICAL STRATEGIES IN VIRTUAL LEARNING ENVIRONMENTS: \\ A STUDY IN COLOMBIA
}

\author{
Dr. Carmen RICARDO-BARRETO \\ ORCID: 0000-0002-0474-685X \\ Department of Education (IESE), Universidad del Norte \\ Barranquilla, COLOMBIA
}

Dr. Humberto LLINAS-SOLANO

ORCID: 0000-0002-2976-5109 Department of Mathematic and Statistic, Universidad del Norte Barranquilla, COLOMBIA

Dr. Antonio MEDINA-RIVILLA ORCID: 0000-0002-1483-0668 Faculty of Education, UNED Madrid, SPAIN

Dr. Maria Luz CACHEIRO-GONZALEZ ORCID: 0000-0001-7865-1362.

Faculty of Education, UNED Madrid, SPAIN

Alexander VILLEGAS-MENDOZA

ORCID: 0000-0002-3538-7212 Department of Economics, Universidad del Norte Barranquilla, COLOMBIA

Dr. Andrea LAFAURIE

ORCID: 0000-0002-6686-2194

Department of Education (IESE), Universidad del Norte Barranquilla, COLOMBIA

Vanessa NAVARRO ANGARITA

ORCID: 0000-0001-7223-6547 Departament of Education (IESE), Universidad del Norte Barranquilla, COLOMBIA

Received: 12/012/2020 Accepted: 07/05/2021 


\section{ABSTRACT}

This article presents the results of the first phase of the project "Design, development and evaluation of an App to promote the development of Intercultural Competence and ICT Competence in teachers of Higher Education" that was carried out in the Department of Antioquia in Colombia. The main objective of the first phase of the study was to analyze the perceptions of higher education teachers about their Intercultural Competence "Culturally Appropriate Pedagogical Strategies" in Virtual Learning Environments. The study has a quantitative approach, with a descriptive and non-experimental design that allows observing and analyzing the phenomena of the study. To identify participants' perceptions, a survey was conducted in which 69 teachers from various educational institutions in the Department of Antioquia in Colombia participated voluntarily.

Keywords: Intercultural competences, online learning, intercultural pedagogical practice, virtual learning environment.

\section{INTRODUCTION}

Intercultural competence is an emerging concept that has a great impact on the university context, with special emphasis on the training of teachers at various educational levels, acquiring an essential place for secondary education teachers, who are the true architects of the implementation of a comprehensive education and attention to educational diversity, as reflected in some research (Dominguez, 2006, 2015; Medina et al. 2010). In Latin America university context, twelve essential competencies have been identified (Medina, 2013) for the improvement of teaching-learning processes, with intercultural being the least appreciated, as it is associated with other competencies such as innovation, research and institutional. Some authors such as CE (2018) and Rodriguez-Izquierdo (2015) consider that the intercultural competence is one of the keys to lifelong learning that every educator should have in order to know how to work with diverse students and also to be able to teach it to others. Hiller and Wozniak (2009) have defined it by recognizing the holistic dimensions from the attitudes, knowledge and skills to interact effectively and appropriately in intercultural situations, highlighting the need for reflective practice in context, so that we are able to recognize and accept visions different from our own.

Another important factor, according to pedagogical trends and the dynamics of flexible education, is the need to address the intercultural competence of teachers in virtual learning environments. At present, there are several training modalities recognized, such as Learning Environment Enhanced with Technology, Online Learning Environment and Blended Learning Environment. In this way, it is evident that information and communication technologies provide us with the opportunity for greater virtual contact with culturally diverse people and that according to Schmelkes (2004), they lead us to a reflection on our cultural references versus those of the people with whom we interact. According to Navarro et al. (2018), there are several methods and processes of teaching-learning that favor the development of Intercultural Competence in environments mediated by ICTs. In this study, we value the pedagogical guidelines defined by Ricardo (2017) for the design of virtual environments of intercultural learning in which the competences and the teacher role are evidenced from the technological and intercultural dimensions.

In this research, intercultural competence is understood from the perspective of a virtual tutor or teacher who assumes the role of intercultural advisor of the teaching and learning process (Arredondo et al., 1996; Byram, 2008; Gomez Zermeno; 2009; Malik, 2003; Ricardo, 2017; Sue et al., 1992; Sue \& Sue, 1990). From this approach, the proposal of basic competencies required in an intercultural approach is considered to be constituted by three sub-competencies, which include three dimensions that are attitudes, knowledge and skills or abilities, which are equivalent to the three domains of the Bloom's taxonomy (Bloom, 1956; Krathwohl, 1973): cognitive (mental skills, knowledge), affective (growth in feeling an emotional areas, attitude) and psychomotor (manual and physical skills, skills). The sub-competencies are grouped as follows:

- Beliefs and attitudes, knowledge and skills of the virtual teacher about the awareness of their own values and prejudices

- Beliefs and attitudes, knowledge and skills of the virtual teacher about the cultural perspective of the student.

- Beliefs and attitudes, knowledge and skills of the online teacher about culturally appropriate strategies.

In this paper we analyze the third sub-competency related to the pedagogical strategies applied by a teacher to design flexible learning environments that promote the intercultural competences of students. For each dimension (Attitudes, Knowledge and Skills), indicators are recognized that make it possible to identify the level of development of this competence (Table 1). 
Table 1. Indicators by Dimensions of the Competence "Culturally Appropriate Pedagogical Strategies"

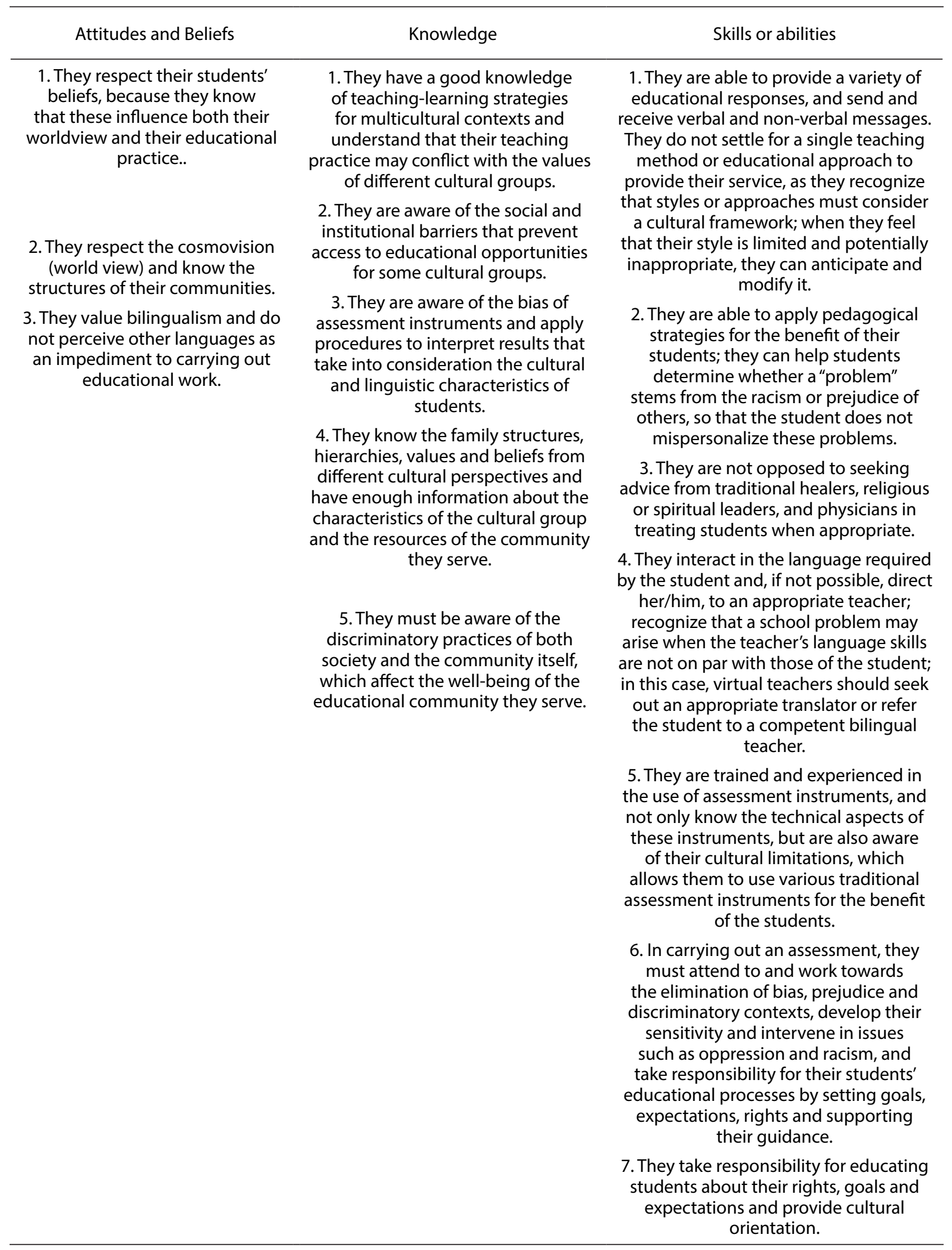

Although the development of students' intercultural competence is a joint work of students and teachers, in the case of this study, focusing on teachers, the fundamental requirement is teacher training. One training strategy is the design of integrated didactic units oriented to the intercultural competence, configuring training situations, which are isomorphic to those that will be worked with the students (Dominguez et al., 2018; Medina, 2017, 2018, 2019) as well as generating a training spiral typical of innovative didactic laboratories, 
as confirmed by other researches (Baches \& Sierra, 2019; Dervin et al., 2012; Garrote \& Fernandez, 2016). The contributions of these investigations confirm that the mastery of intercultural competence by teachers is intermediate, which evidences the necessary updating and professional development of teachers in this priority competence. Dominguez et al. (2012) research also confirms that university teachers must continue to seek harmony and training in intercultural competence in close relation to what is intended by secondary school teachers, with a singular focus on interaction with communicative, social and intercultural dialogue skills.

There is also a need for more extensive and justified training in the field of intercultural competence for teachers, with emphasis on the challenge of the first university year (Dominguez et al., 2018; Medina et al., 2019). It is highlighted the need to address the challenges that future generations of teachers will experience, especially those who share their lives with other colleagues (Gomes et al., 2014; Yilmaz, 2016), in culturally diverse realities (Baches \& Sierra, 2019; Bakker \& Avest, 2019; Benson, 2019; Moreira et al., 2019; Quintriqueo et al., 2017; Vogt, 2016). These authors recognize the incidence and potentialities in the development of the intercultural competence, on having applied the principles of flexibility and collaboration and, at the same time, on involving intensely in the multiple visions and contributions of the respective areas, from the plastic, religious and musical education, especially regarding the knowledges and disciplines that contribute the numerous and adaptive forms of working the intercultural education.

Training in intercultural competence is understood as a dialogic-transformative process based on social justice, building a creative circle. The aim is to give teachers back a new awareness and meaning of the ways of knowing, acting, being and living together in the knowledge society and in the face of the impact of educational technologies. In this sense, Ricardo (2017) notes that the training processes must promote a global vision that makes the educational community aware of the prevailing need to favor more inclusive educational models where cultural aspects must be integrated into the curriculum.

Similarly, it should be noted that the results of some studies (Borjas et al., 2014; Iriarte et al., 2015; Navarro et al., 2018; Ricardo, 2017; Ricardo-Barreto, et al. (2020) show that teachers have deficiencies in the use of both ICT tools and interculturalism in the classroom. This makes it necessary to think about training processes that link both competencies, and that aim at strengthening ICTs and intercultural competencies. In this way teachers can assume the role of designers and tutors of virtual environments for intercultural learning.

According to the findings of this research, there is a need for awareness raising and training to develop intercultural competence. In this way, virtual teachers will be able to adequately use the cultural elements present in the communities as a support. In such a way that the multicultural presence is recognised and handled appropriately in virtual learning environments. Likewise, it is necessary for universities to assume, as an institutional policy, the education and training of their teachers in intercultural education. Course content should include topics such as the design of teaching-learning strategies that take into account the role of cultural and ethnic differences in teaching practice. Similarly, intercultural educational evaluation and the importance of culture in the integral formation of the human being, among other topics, should be handled.

Ruiz-Cabezas and Medina (2014) claim an education characterized by a global and reforming educational approach to educational practice should facilitate interaction and intercultural dialogue.

\section{INTERCULTURAL COMPETENCE AND THE PRINCIPLE OF DIALOGUE}

The understanding of intercultural competence from the meaning and transformation of the dialogical process has been proposed by various authors (Dominguez, 2006; Huber, 2014; Ruf and Gallin, 1998). These authors have delved into the transformation of the intra-, inter- and multi-personal meaning of the dialogical principle and the relevance of training students in the use and development of the "learning notebook". This vision, which generates a new culture of diversity of people and teachers, has been made explicit in research (Dominguez et al., 2018). It also highlights the significance of new approaches (dialogicinterpersonal) that enrich each teacher and resituate him or her in the face of the great challenge of new cities, human ecosystems and cross-border dialogue. These challenges bring new ways of understanding 
dialogue between people across borders, and the value of richness, commitment and genuine collaboration between human beings.

According to Kourova and Modianos (2013), students are considered unprepared for culturally diverse encounters, and may face difficulties when interacting with other cultures different from their own. Therefore, formative scenarios could be offered that minimize that gap and can be adapted to global perspectives to encourage culturally appropriate behaviors. In this sense, teachers, from their training role, can promote intercultural communication and foster positive attitudes and understanding of other people to lead to tolerance, overcoming stereotypes and reducing prejudice and self-centeredness (Kourova \& Modianos, 2013; Wang et al., 2020).

On the other hand, Thapa (2019) analyzes the importance of developing intercultural competence as a fundamental strategy in teacher training, to strengthen intercultural sensitivity and communication in newly trained teachers, and thus foster skills and knowledge related to consideration, criticality, and cultural sensitivity. She highlights the gap in relationships that exists between teachers and culturally diverse students, which causes these students to leave the school systems. To close this gap, training processes to strengthen intercultural communication skills and the application of pedagogical strategies appropriate to the new realities may be relevant.

\section{POSSIBILITIES OF TECHNOLOGICAL RESOURCES AND VIRTUAL LEARNING ENVIRONMENTS IN INTERCULTURAL COMPETENCE}

The technological resources favor the intercultural approach from its possibilities for synchronous or asynchronous information and communication (Ciftci, 2016; Cruz et al., 2019), as well as to overcome stereotypes and prejudices (Rodriguez-Izquierdo, 2015), offering a wide range of possibilities to create learning communities based on interculturality (Garrote et al., 2018). These resources (educational platforms, web 2.0 resources, and others) offer an adequate framework to enrich the interactions between teachers and students (Cacheiro et al., 2019). These technologies and other emerging ones such as App (Moreno et al., 2016) or virtual reality (Rodriguez-Garcia et al., 2019) allow to experience other realities without spatialtemporal limitations, promoting the involvement of teachers and students in the classroom and virtually and reducing the digital gap. On the other hand, the Apps provide flexibility, availability and interactive force, which contribute to the communicative, digital and cultural dialogue competences. An example is the CrossCult project that has allowed in its pilot phase to create a mobile web platform for historical and cultural content (Daif et al., 2018).

This new dialogical approach brought about by the advance in digital competence questions the typology of coherent technological resources (Cacheiro, 2011, 2016), in order to respond to the multifaceted and changing modalities of use and impact on the development of intercultural competence. Studies on the use of ICTs to promote language and cultural learning and increase intercultural competence show that intercultural competence improved with the use of these technological mediations, especially through the interaction presented for video creation and exchange and classroom discussion (Chiper, 2013; Wang et al., 2020; Yeh, 2018).

Authors such as Aguaded et al. (2013), Navarro et al. (2018), Ricardo (2017) and Valverde (2010) consider that a teacher who assumes a role of guidance in the virtual classroom and with intercultural competencies must have the ability to identify his or her culture, beliefs and attitudes and those of others; to accept and respect worldviews and differences; to strive to reduce stereotypes, prejudice, racism from the teaching and learning process and any type of discrimination by race, gender, age, among others. The teacher becomes a guide, a mediator of the process that allows affective and effective interaction within the virtual environment privileged by the intercultural pedagogical practice (Ricardo, 2017).

This implies, however, an intercultural and technologically competent teacher. In this sense, Ricardo (2017) presents some pedagogical orientations of a constructivist and socio-cognitive approach that takes elements from the artistic and socio-communicative theory (Medina, 2009), which serve as a guide for the design of virtual environments of intercultural learning. The aspects to be considered are: the context of virtual teaching and learning, the conception of learning, the actors of the process (teacher and student), the interaction, the virtual learning environment, the educational materials, the tasks and learning activities and the evaluation of learning. 


\section{PURPOSE OF THE STUDY}

Previous studies by Essomba (2006), Gosselin and Meixner (2013), Jordan (2001), and Ricardo et. al (2017) show that teachers are not able to identify culturally appropriate strategies, even when they apply them. Teachers also express the development of intercultural projects, but unconsciously reinforce stereotypes and prejudices. According to these authors, it is important for teachers to have the ability to understand the cultural context of the class in which they teach, and to be aware of their intercultural educational practice, without forgetting or annulling their own

This study focuses on higher education teachers and on the level of development of their inter-cultural competence "Culturally Appropriate Teaching Strategies". Therefore, the following questions are considered:

1. What is the level of development of the dimension "Attitudes" of the competences of higher education teachers in the Department of Antioquia?

2. What is the level of development of the dimension "Knowledge" of the competence of teachers of higher education of the Department of Antioquia?

3. What is the level of development of the dimension "Skills and Abilities" of the competence of higher education teachers of the Department of Antioquia?

\section{METHOD}

The study reported here was conducted on teachers of Higher Education in the Department of Antioquia in Colombia. The study has a quantitative approach, with a descriptive, non-experimental design that allows the study phenomena to be observed and analyzed in the way they occur without any modification or manipulation (Creswell \& Creswell, 2017). The next sections describe the sample and identify details of the instrument used.

\section{Participants}

Socio-demographic characteristics of participant teachers of Colombia are as follows: 69 teachers $(29 \%$, women and $71 \%$, men). In terms of age, 36.2\% were between 31 and 40, 36.2\% between 41 and 50, and $24.6 \%$ were over 50 , while the remaining $2.9 \%$ were between 21 and 30 years old at the time of application. On the other hand, 90\% came from Antioquia, more specifically, 68\% from Medellin and 3\% from Armenia. Regarding the workplace, 45\% work at the University of Medellin, 35\% at the University of San Buenaventura, $12 \%$ at the University of Antioquia, the Digital University of Antioquia with $4 \%$ and the Pontifical Bolivarian University with 3\%. Consequently, 84\% work in Medellin, and the rest in other locations in Antioquia. Likewise, academic programs in Economics, Administration, Accounting and related careers are the most frequent among participants, representing 33\%, followed by Social and Human Sciences with 26\% (Figure 1). 42\% of the teachers expressed that they had between 1 and 10 years of experience, $28 \%$ between 11 and 20 years, and the remaining 26\% had more than 21 years of teaching experience (Figure 2). 


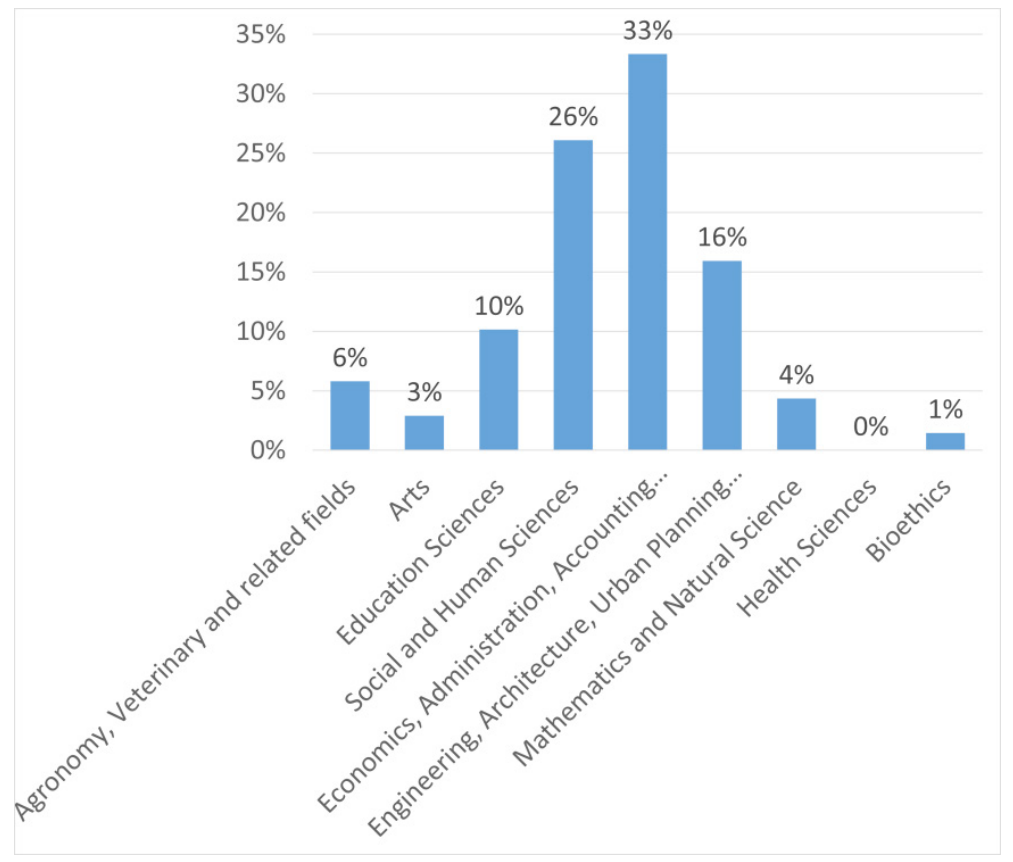

Figure 1. Distribution of the sample according to the performance area

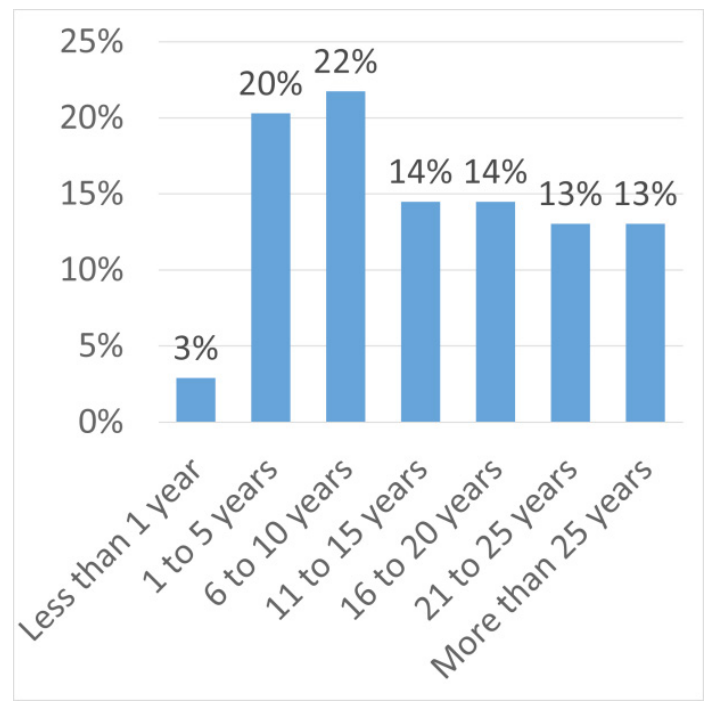

Figure 2. Distribution of the sample according to years of experience

\section{Data Collection and Analysis}

To collect the data for the study, a digital survey was applied in various institutions of the Department of Antioquia given the emphasis of the call in which the project was funded. Teachers from participating institutions volunteered to participate in the project. The results would be used as an input for the next phase of the project, which consisted of the Design of an App for the Self-Training of Higher Education Teachers in Intercultural Competence and ICT Competence. From the data collected, a descriptive study was carried out in order to identify the characteristics of the selected sample.

For the analysis of the quantitative results, goodness of fit tests were applied (Llinas, 2006), in order to study if the percentage of the answers given by the teachers is distributed uniformly or not at a population level, taking into account the different categories of response of the survey that will be described later (Very good, Good, Fair and Poor). 


\section{The Scale}

A four-point Likert-type scale entitled "Intercultural competences of the virtual teacher" developed by Ricardo (2017) was used to determine the levels of Intercultural competences of higher education teachers. The scale consists of 80 questions corresponding to three sub-dimensions (Attitudes, Knowledge and Skills) in the three sub-competences included: Awareness of one's own values and prejudices, Cultural Perspective of the student and Culturally Appropriate Pedagogical Strategies of the teaching staff. In each Dimension, indicators are defined (see Table 1) that facilitate the analysis and interpretation of the results. The Cronbach Alpha internal consistency coefficient of the scale was .964, which shows a high correlation between the instrument items for each variable. This paper focuses only on the sub-competence of Culturally Appropriate Teaching Strategies, and all the analyses were carried out on these three sub-dimensions of Attitudes, Knowledge and Skills.

The instrument categories used are "Very Good", "Good", "Fair" and "Poor", and the scores assigned to each category are 4, 3, 2 and 1, respectively. These can be defined as follows (Ricardo, 2012, p. 34):

- "Very good": the respondent's answer evidences a high knowledge, attitude, and ability very favorable to the development of the intercultural competence of him/herself and his/her students.

- "Good": the answer of the interviewee evidences an adequate knowledge and a not very favourable attitude and ability towards the development of the intercultural competence of him/herself and his/ her students.

- "Fair": the response of the interviewee evidences low knowledge, an unfavorable attitude and skills towards the development of the intercultural competence of him/herself and his/her students.

- "Poor": the answer of the interviewee shows a lack of knowledge, an unfavourable attitude and skills towards the development of the intercultural competence of him/herself and his/her students.

\section{FINDINGS}

The results obtained are described below, presenting the results of the teachers' perceptions of intercultural competence taking into account the dimensions and criteria defined in each of them.

\section{Teachers' Perception from the "Attitudes and Beliefs" Dimension}

Table 2 presents the results taking into account the indicators of the "Attitudes and Beliefs" dimension.

Table 2. Results (by indicator) in the "Attitudes and Beliefs" dimension of Sub-competency III

\begin{tabular}{|c|c|c|c|c|c|c|}
\hline \multirow{3}{*}{$\begin{array}{l}\text { Ind. } \\
\qquad 1\end{array}$} & \multicolumn{4}{|c|}{ Frequency and percentages (\%) } & \multirow{2}{*}{$\frac{X}{{ }^{*}}$} & \multirow[t]{2}{*}{ df } \\
\hline & Poor & Fair & Good & Very Good & & \\
\hline & $0(0.00)$ & $3(4.35)$ & $42(60.87)$ & $24(34.78)$ & 33.13 & 2 \\
\hline 2 & $2(1.45)$ & $10(7.25)$ & $81(58.70)$ & $45(32.61)$ & 113.88 & 3 \\
\hline 3 & $1(1.45)$ & 11 (15.94) & $28(40.58)$ & $29(42.03)$ & 32.28 & 3 \\
\hline
\end{tabular}

Note: Ind. = Indicator; $X=$ Chi-square statistic; $d f=$ Degrees of freedom;

(*) It is always fulfilled that $P$-value $<0.05$

Because P-value $<0.05$, with a $95 \%$ confidence level, we can say that the percentages of responses given by respondents for each of the categories (Good, Very Good, Fair, and Poor) are not equal. In all the indicators, 
it is important to highlight the fact that the response percentage in the categories Poor or Fair was less than $16 \%$ and, even more so, in the first category the maximum percentage was $1.45 \%$, with some percentages of $0.00 \%$.

In indicator 3 of the Attitudes dimension (They value bilingualism and do not perceive other languages as an impediment to carrying out educational work), no statistically significant difference was found between the response proportions corresponding to the categories Good or Very Good. In indicator 1 (Respect the beliefs of their students, because they know that these influence both their world view and their educational practice) and indicator 2 (Respect the world view and know the structures of their communities) of this same dimension, a higher proportion is found in the Good category.

\section{Perception of Teachers from the "Knowledge" Dimension}

Table 3 presents the results taking into account the indicators of the "Knowledge" dimension.

Table 3. Results by indicators in the "Knowledge" dimension of Sub-competency III

\begin{tabular}{|c|c|c|c|c|c|c|}
\hline \multirow{2}{*}{ Ind. } & \multicolumn{4}{|c|}{ Frequency and percentages (\%) } & $\mathrm{x}$ & \multirow[t]{2}{*}{ df } \\
\hline & Poor & Fair & Good & Very Good & $(*)$ & \\
\hline 1 & $9(4.35)$ & $61(29.47)$ & $94(45.41)$ & $43(20.77)$ & 72.94 & 3 \\
\hline 2 & $7(5.07)$ & $35(25.36)$ & $76(55.07)$ & 20 (14.49) & 77.94 & 3 \\
\hline 3 & $32(11.59)$ & $69(25.00)$ & $128(46.38)$ & 47 (17.03) & 77.30 & 3 \\
\hline 4 & $7(3.38)$ & $24(11.59)$ & $115(55.56)$ & $61(29.47)$ & 132.54 & 3 \\
\hline 5 & $0(0.00)$ & $1(1.45)$ & $33(47.83)$ & $35(50.72)$ & 31.65 & 2 \\
\hline
\end{tabular}

Note: Ind. = Indicator; $X=$ Chi-square statistic; $d f=$ Degrees of freedom;

(*) It is always fulfilled that $P$-value $<0.05$

Because P-value $<0.05$, with a $95 \%$ confidence level, we can say that the percentages of responses given by respondents for each of the categories (Good, Very Good, Fair, and Poor) are not equal. In all the indicators (except indicator 3), the fact that the response percentage in the Poor category was less than $6 \%$ is highlighted, and even more so, there is an indicator that has a percentage of $0.00 \%$ (indicator 5 [They must be aware of the discriminatory practices of both society and the community itself, which affect the well-being of the educational community they serve]).

For all indicators, the highest proportion of responses is in the categories Fair, Good or Very Good. There is no homogeneity in the results found for each indicator and each dimension. For this reason, we will compare these three proportions in each case.

In indicators 1, 2 and 3, the highest proportion is concentrated in the response categories Fair and Good, with the latter being higher.

Indicator 4 (They are aware of family structures, hierarchies, values and beliefs from different cultural perspectives and have sufficient information about the characteristics of the cultural group and the resources of the community they serve) and indicator 5 (They should be aware of discriminatory practices in both society and the community itself that affect the well-being of the educational community they serve) show a lower proportion of teachers in the Poor and Fair categories. In These indicators, the highest proportion is concentrated in the response categories Good or Very Good, with the former being higher. In indicator 5, no statistically significant difference is observed between these two response proportions. 


\section{Perception of Teachers from the "Skills or Abilities" Dimension}

Table 4 presents the results taking into account the indicators of the dimension "Skills".

Table 4. Results by indicators in the "Skills or abilities" dimension of sub-competency III

\begin{tabular}{|c|c|c|c|c|c|c|}
\hline \multirow{2}{*}{ Ind. } & \multicolumn{4}{|c|}{ Frequency and percentages (\%) } & $x$ & df \\
\hline & Poor & Fair & Good & Very Good & \multicolumn{2}{|c|}{$(*)$} \\
\hline 1 & $8(2.32)$ & $38(11.01)$ & $181(52.46)$ & $118(34.20)$ & 213.76 & 3 \\
\hline 2 & $1(1.45)$ & $2(2.90)$ & $41(59.42)$ & $25(36.23)$ & 64.97 & 3 \\
\hline 3 & $1(1.45)$ & $9(13.04)$ & $44(63.77)$ & $15(21.74)$ & 61.03 & 3 \\
\hline 4 & $33(15.94)$ & $59(28.50)$ & $60(28.99)$ & $55(26.57)$ & 9.33 & 3 \\
\hline 5 & $11(7.97)$ & $23(16.67)$ & $71(51.45)$ & $33(23.91)$ & 58.52 & 3 \\
\hline 6 & $9(4.35)$ & $44(21.26)$ & $103(49.76)$ & $51(24.64)$ & 87.24 & 3 \\
\hline 7 & $0(0.00)$ & $10(7.25)$ & $74(53.62)$ & $54(39.13)$ & 46.61 & 2 \\
\hline
\end{tabular}

Note: Ind. = Indicator; $X=$ Chi-square statistic; $d f=$ Degrees of freedom;

(*) It is always fulfilled that $P$-value $<0.05$

Because P-value $<0.05$, with a $95 \%$ confidence level, we can say that the percentages of responses given by respondents for each of the categories (Good, Very Good, Fair, and Poor) are not equal. In all the indicators, except for indicator 4 (Interact in the language required by the student and, if not possible, direct them to an appropriate teacher; recognize that a school problem may occur when the teacher's language skills are not on par with those of the student; in this case, virtual teachers should seek an appropriate translator or refer the student to a bilingual and competent teacher), the fact that the response percentage in the Poor category was less than $8 \%$ is highlighted, and, even more, an indicator with a percentage of 0,00 is presented (indicator 7: They take responsibility for educating students about their rights, goals and expectations and provide culturally appropriate guidance).

Summarizing, in all indicators, the highest proportion of responses corresponds to the categories Fair, Good or Very Good. There is no homogeneity in the results found for each indicator and each dimension. For this reason, we will compare these three proportions in each case.

In indicator 1 (they are able to provide a variety of educational responses; send and receive verbal and non-verbal messages; do not settle for a single teaching method or educational approach to provide their service, as they recognize that styles or approaches must consider a cultural framework; when they feel that their style is limited and potentially inappropriate, they can anticipate and modify it), indicator 2 (they are able to apply pedagogical strategies for the benefit of their students; can help students determine whether a "problem" stems from the racism or prejudice of others, so that the student does not mispersonalize these problems), indicator 3 (do not object to seeking advice from traditional healers, religious or spiritual leaders, and physicians in treating students when appropriate), and indicator 7 , the largest proportion concentrates on the response categories Good and Very Good, with the former being larger. For indicator 4, there is no statistically significant difference between the response rates for the categories Fair, Good or Very Good. In indicator 5 (they have training and experience in the use of evaluation instruments, and are not only aware of the technical aspects of these instruments, but also of their cultural limitations, which allows them to use various traditional evaluation instruments for the benefit of the students) and indicator 6 (When carrying out an evaluation, they should pay attention to and work on the elimination of bias, prejudice and discriminatory contexts, develop their sensibility and intervene in aspects such as oppression and racism, but they also take responsibility for the educational processes of their students, establishing goals, expectations, rights and supporting their orientation), we found that there is no statistically significant difference between the response proportions corresponding to the categories Fair and Very Good, but at the same time, these proportions are statistically lower than the response proportion of the category Good. 


\section{DISCUSSIONS AND CONCLUSIONS}

Results will be discussed according to the dimensions of the sub-competency studied, that is, Attitude and Beliefs, Knowledge, and Skills or Abilities. Regarding the dimension "Attitude and Beliefs", results indicate that the majority of teachers consider that they respect the beliefs of their students and their worldviews, have a knowledge of the social structures of the communities present in the classroom, and give importance to the mastery of languages because they consider that it affects their intercultural pedagogical practice (Gomez, 2009; Ricardo, 2017), which is recognized with special relevance (Chiper, 2013; Yeh, 2018; Wang, et al., 2020), because sharing language as a code gives education the inherent sense of putting in common, connecting education with communication in an intercultural sense. However, there is a proportion of teachers that, in the three indicators, are in the category of Poor and Fair, that is, they consider that they do not have a mastery of their intercultural competence in the dimension of Attitudes and Beliefs. They are not aware of the cultural differences in the classroom, nor of the importance of applying culturally appropriate pedagogical strategies. In this way, according to Ricardo (2017), Dominguez et al (2018), and Navarro et al. (2018), it is necessary to sensitize and train the academic community, especially the faculty, to incorporate elements of cultures for the strengthening of the learning process in students, as well as the dialogue between cultures. Findings also indicate that teachers still need to advance in strengthening their Attitude dimension to generate learning scenarios that recognize differences and diversity in any training modality, and thus overcome the impediments that may arise in their educational work from the attitudinal dimension.

According to the results of the "Knowledge" dimension, they indicate that there is a high proportion of teachers at the institution who know teaching and learning strategies that integrate the intercultural dimension in the classroom, and also have a critical attitude towards the institutions where they work that allows them to identify strategies to promote or not respect for differences and diversity. Likewise, the results show that a proportion of teachers have assumed evaluative practices as being linked to intercultural training. However, according to the findings, in the Fair category, a significant percentage of teachers state that they do not have knowledge of multiculturalism in the classroom, which is consistent with the intermediate level of intercultural competence reported by researchers in other contexts (Baches \& Sierra, 2019; Dervin et al., 2012; Garrote \& Fernandez, 2016 They also claim that they do not know how to apply teaching and learning strategies and evaluative practices that promote intercultural encounters in favor of training in student diversity from any modality (virtual, face-to-face, combined, distance) (Ricardo, 2017; Dominguez et al., 2012). In particular, some authors note deficiencies in the intersection between the use of ICT tools and teachers' intercultural competence (Borjas et al., 2014; Iriarte et al., 2015; Navarro et al., 2018). In general terms, results in this dimension indicate that the vast majority of faculty members have knowledge of the cultural groups in their institution's academic community and are also aware of the discriminatory practices that affect the well-being of these communities. According to Ricardo (2017) it is necessary to advance in the design of institutional policies related to the formation of the educational community in the design of teaching and learning strategies and evaluative practices with an intercultural approach.

Regarding the "Skills or Abilities", results indicate that a representative proportion of teachers have the skills and abilities to apply different teaching methods and pedagogical strategies that integrate the culture of the communities represented in the classroom, and identify problems that stem from racism, prejudice or stereotypes that can affect the teaching and learning process and the relationships among the actors in the process. They recognize their cultural limitations and how to overcome them to the benefit of their pedagogical practice and student training, providing adequate cultural orientation when required. They appear to have language skills and seek solutions when this need arises in virtual or face-to-face training. In this same sense, they attend to and work on the elimination of bias and discriminatory elements in evaluation instruments to promote more inclusive practices. Such results seem promising, since teachers would have the ability to develop an inclusive practice, which from the doing would consider the differences and diversities existing in the classrooms. However, in this dimension, we find that there is a proportion of teachers who do not have these skills and abilities and that deserves their attention from processes of sensitization; these teachers do not take into account the needs of students or their cultural references when they select didactic methods and design learning strategies and activities, or when they select and design educational resources or evaluation strategies that are sensitive to the cultural plurality of the classroom (Ricardo, 2017). This situation highlights the need to strengthen intercultural competence, since the gaps 
generated between some students and others would be notorious for the impossibility for teachers to make adaptations to their strategies, teaching methods and designs. Thapa (2019) also highlights the gap between students and teachers, proposing as a solution the training processes aimed at strengthening intercultural communication skills and the application of pedagogical strategies.

The findings of the three sub-components show that strengthening teacher training processes from an intercultural perspective is both desirable and necessary. In addition, it is important to do so in contexts and conditions that favor its materialization, among them, virtual learning environments and those mediated by technologies, which favor an adequate framework to enrich interactions (Cacheiro et al., 2019).

As a conclusion, the results of the study show that the three components of the sub-competency, "Culturally Appropriate Strategies", tend to have a higher proportion of responses in the categories Good, Very Good or Fair, which can be interpreted as encouraging the intercultural competence of teachers, thinking about the possibility of a more inclusive education. However, by deepening the analysis it is possible to detect that the components "Attitudes and Beliefs" and "Skills or Abilities" present better results than the component of "Knowledge". That is to say, teachers feel more qualified to develop intercultural teaching practices from what they believe or think they know how to do, than from the knowledge they think they have of the culturally appropriate strategies to develop their teaching work from an intercultural perspective. In responding, they honestly show that they do not necessarily have knowledge of each of the indicators referred to in that knowledge. In this sense, it is possible that the skills and attitudes of teachers to face intercultural situations are mediated by some ignorance, and although it is considered to act taking into account the intercultural contexts, it may not be experienced in practice. The literature considers the complementarity of the three components: "Attitudes and Beliefs", "Knowledge" and "Skills or Abilities" (Hiller \& Wozniak, 2009; Rodriguez-Izquierdo, 2015).

Acknowledgements: Acknowledgements of, funds of Minciencias and Antioquia Department at Colombia, cofinancial by Universidad del Norte and Universidad de San Buenaventura de Medellin at Colombia.

\section{BIODATA and CONTACT ADDRESSES of AUTHORS}

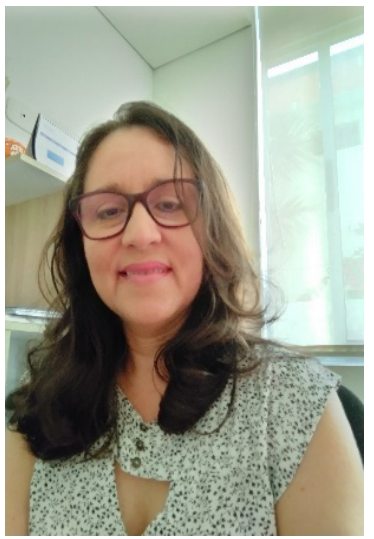

Carmen RICARDO-BARRETO is a Professor of Educational Technology at Education Department, Universidad del Norte. Dr. Ricardo-Barreto gained his Ph.D. in Technology, Interculturality and Didactics Model at July, 2012. Her academic interest areas are design of learning environment using ICT (online learning, b-learning and enhance environment using ICT), Strategic Planning to integrate ICT in the areas of educational management, Intercultural Education and intercultural competences in faculty and students. She has over than 15 journal articles published in international indexes, 1 international book chapters and other national and international articles, papers submitted to international meetings. She was involved in many projects related to ICT an intercultural education on preschool, primary, secondary and higher education. She has been a students advisor master's and doctorate research projects.

Carmen RICARDO-BARRETO

Department of Education

Address: Universidad del Norte, Barranquilla, Colombia

Phone: +573002732454 ,

E-mail: cricardo@uninorte.edu.co 


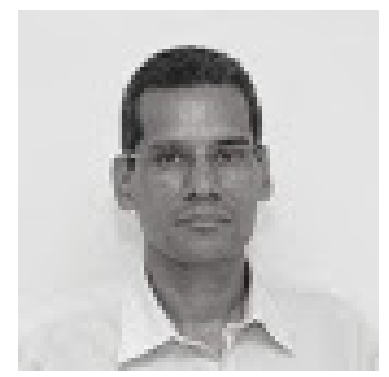

Humberto LLINAS SOLANO has a degree in Education Sciences, with emphasis in Mathematics, Physics and Statistics from the Universidad del Atlantico (Colombia). He holds a M. A. in Math. He is Doctor in Statistics from the Johannes Gutenberg University of Mainz (Germany). Now-adays he belongs to two (2) research groups. He has in his track record the publication of eight (8) books and 27 papers in national and interna-tional journals, on different fields of knowledge. During 2008-2021 he has presented three (3) projects financed by the Research and Projects Di-rection (Direccion de Investigacion \& Proyectos DIDI) in Universidad del Norte, 3 more financed by Colciencias (Colombia) and 1 more financed by OPS. He has supervised 17 students in Postgraduate Programs in Applied Statistics to the completion of their degrees (2004-2021).

\section{Humberto LLINAS SOLANO}

Department of Mathematic and Statistic

Address: Universidad del Norte, Barranquilla, Colombia

Phone: +57 3509294,

E-mail: hllinas@uninorte.edu.co

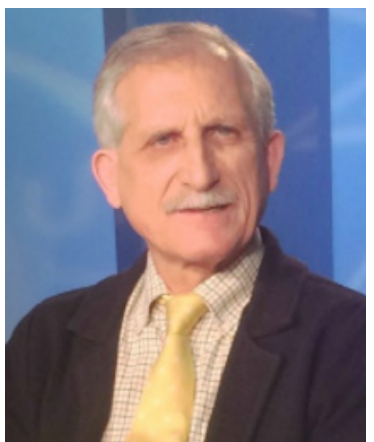

Antonio MEDINA-RIVILLA is Emeritus Professor at the UNED, Spain, in the area of Teaching and School Organization. Dr. Medina gained his Ph.D. in Philosophy and Educational Sciences. Has been Director of Department for more than 25 years. He has directed over 100 doctoral theses and numerous research papers in Spanish and international context. He has developed numerous national and international $R \& D$ projects, with a great impact on scientific network discussion (ECER, ISAAT, RIAICES, etc.). Professor Honoris Causa of IUNIR (Argentina) and the University of Santander (Mexico) in 2015 and has won special recognition as professor and researcher at the University of Latvia, Riga (Latvia) in 2015.

Antonio MEDINA-RIVILLA

Instructional Design Department, Faculty of Education

Address: Universidad Nacional de Educacion a Distancia (UNED, Juan del Rosal, 14, 28040 Madrid, Spain Phone: +34 913986969

E-mail: amedina@edu.uned.es

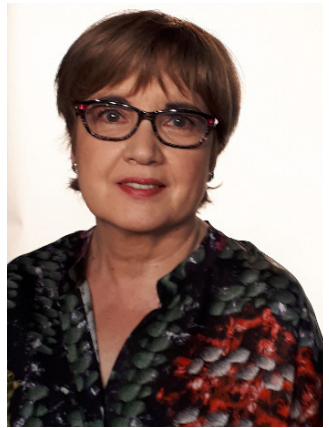

Maria Luz CACHEIRO-GONZALEZ is a Professor at the UNED, Spain, in Teaching and School Organization area. Dr. Cacheiro gained her Ph.D. in Education Sciences. She received her B.A. Degree in Education and Psychology from the Complutense University, Madrid, Spain. She is Professor at the Faculty of Education at the UNED, Spain. Secretary of the Master in Strategies and Technologies for Teaching Role in Multicultural Society Education Department. Coordinator of the Media, Technology and Resources Socio Intervention Level of Social Education Degree. Among his current research are "Evaluating web resources" and "the digital portfolio as a strategy for teaching and learning".

\section{Maria Luz CACHEIRO-GONZALEZ}

Instructional Design Department, Faculty of Education

Address: Universidad Nacional de Educacion a Distancia (UNED), Juan del Rosal, 14, 28040 Madrid, Spain Phone: +34 913988878

E-mail: mlcacheiro@edu.uned.es 


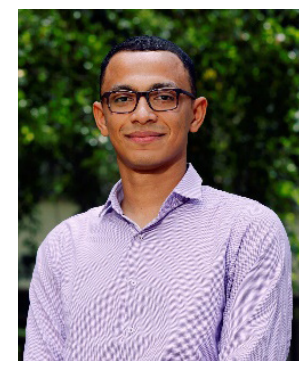

Alexander VILLEGAS-MENDOZA is a professor since 2018 at the Universidad del Norte and is an economist from the same university. Education as a mechanism to overcome poverty is one of his main motivations and area of interest. He has master's degrees in Economics and Public Policy from the Universidad de Los Andes and has been part of multidisciplinary teams in different projects ranging from impact evaluation to the design of educational policy documents for two municipalities, using quantitative and qualitative methodologies. Likewise, he has been a speaker, winner of calls, co-author and author of a book chapter and three journal articles.

\section{Alexander VILLEGAS-MENDOZA}

Department of Economics

Address: Universidad del Norte, Km.5 Via Puerto Colombia, Postal Code: 081007, Metropolitan Area of Barranquilla, Colombia

Phone: +575 3509509, Ext. 4505

E-mail: villegas@uninorte.edu.co

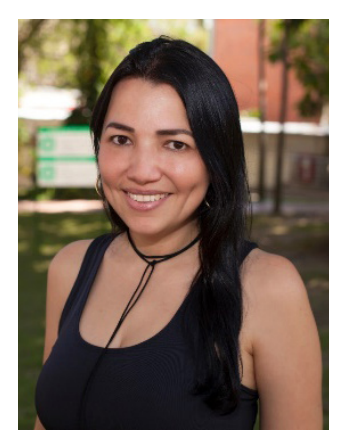

Andrea LAFAURIE-MOLINA is a professor and researcher at Department of Education, Education Studies Institute (IESE), Universidad del Norte. Coordinator of Doctorate in Education Programme. Dr. Lafaurie gained his Ph.D. in Communication Content in the Digital Age at March, 2013. His academic interest areas are Educommunication, Media Education and Literacy, Audiences and reception processes, Realationships of children, adolescents and young people with media and ICT, Interactive and participation of children and youngest audiences. She is author and co-author of articles, book chapters, books, and other national and international publications. She has also participated as a speaker and researcher in national and international project teams.

\section{Andrea LAFAURIE-MOLINA}

Department of Education, Education Studies Institute (IESE)

Address: Universidad del Norte, Km.5 Via Puerto Colombia, Postal Code: 081007, Metropolitan Area of Barranquilla, Colombia

Phone: +5753509509 , Ext. 3436

E-mail: andreal@uninorte.edu.co

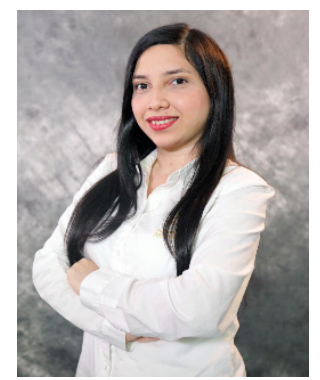

Vanessa NAVARRO ANGARITA is a Professor at the Universidad del Norte. Dean of the Faculty of Education Sciences of the Corporacion Universitaria Americana. Candidate for a $\mathrm{PhD}$ in Humanities, Art and Education from the Castilla de la Mancha University (Spain). Master in Education and Bachelor of Early Childhood Education from the Universidad del Norte (Colombia). She is currently Dean of the Faculty of Educational Sciences at the American University Corporation. Professor of the Bachelor's Degree in Early Childhood Education at the Universidad del Norte. Researcher of the Educational Informatics research groups in the bimodal and classroom lines enriched with ICT (teacher training, intercultural AVAS design) and of the Cognition and Education group in the Childhood line of the Universidad del Norte. He has several journal articles published in international indexes, international and other national book chapters, papers presented at international conferences.

Vanessa NAVARRO ANGARITA

Departament of Education (IESE)

Address: Universidad del Norte, 00000, Puerto Colombia, Colombia

Phone: +57 3043280179

E-mail:vangarita@uninorte.edu.co 


\section{REFERENCES}

Abdullah et al. (2018). A Mobile App to Learn About Cultural and Historical Associations in a Closed Loop with Humanities Experts. Applied Sciences, 9(1), p.9.

Aguaded, E, De la Rubia, P., \& Gonzalez, E. (2013). La importancia de la formacion del profesorado en competencias interculturales (The importance of teacher training in intercultural skills). Profesorado. Revista de curriculum y formacion del profesorado, 17(1), 339-365. https://www.ugr. es/-recfpro/rev171COL6.pdf

Aguado, T. (2003). Pedagogia Intercultural (Intercultural Pedagogy). McGraw Hill

Baches, J. \& Sierra, M.L. (2019). La educacion intercultural y el desarrollo de la competencia intercultural a traves de la asignatura de educacion plastica, visual y audiovisual: retos y oportunidades (Intercultural education and the development of the intercultural competence through the subject of Plastic, Visual and Audio-Visual Education: challenges and opportunities). Profesorado. Revista de Curriculum y Formacion de Profesorado, 23(1), 161-181. DOI:10.30827/profesorado. v23i1.9149

Bakker, C., \& Avest, I. (2019). Teacher training for religious education: Engaging academics through the Dialogical Self Theory. Transformation in Higher Education, 4(1), 1-9.

Benson, A. (2019). Migrant teachers and classroom encounters: Processes of intercultural learning. London Review of Education, 17(1), 1-13

Bloom, B. S. (1956). Taxonomy of Educational Objectives, Handbook I: The Cognitive Domain. David McKay Co Inc.

CE (2018). Recomendacion del Consejo de 22 de mayo de 2018 relativa a las competencias clave para el aprendizaje permanente (Council Recommendation of 22 May 2018 on key competences for lifelong learning). Recuperado de https://eur-lex.europa.eu/legal-content/ES/TXT/ PDF/?uri=CELEX:32018H0604(01)\&from=ES

Cacheiro, M.L. (2011). Recursos educativos TIC de informacion, colaboracion y aprendizaje (ICT educational resources for information, collaboration and learning). Pixel-Bit, Revista de Medios y Comunicacion, 39, 69-81.

Cacheiro, M.L. (2016). Didactica y TIC: diseno de medios y formacion de docentes (Didactics and ICT: media design and teacher training). En E. Lopez (coord.), Didactica general y formacion del profesorado (General didactics and teacher training) (pp. 159-196). UNIR

Cacheiro, M.L., Medina-R., A.M., Dominguez, M.C. \& Medina-D., M.d.C. (2019). The learning platform in distance higher education: student's perceptions. Turkish Online Journal of Distance Education, 20(1), 71-95.

Ciftci, E. Y. (2016). A review of research on intercultural learning through computer-based digital technologies. Educational Technology and Society, 19(2), 313-327.

Creswell, J. W., \& Creswell, J. D. (2017). Research design: Qualitative, quantitative, and mixed methods approaches. Sage publications.

Cruz, M.A., Pozo, M.A., Aushay, H.R., \& Arias, A.D. (2019). Las Tecnologias de la Informacion y de la Comunicacion (TIC) como forma investigativa interdisciplinaria con un enfoque intercultural para el proceso de formacion estudiantil (Information and Communication Technologies (TIC) as an interdisciplinary research form with an intercultural approach to the process of student training). e-Ciencias de la Informacion, 9(1), 1-15. doi:10.15517/eci.v1i1.33052

Daif, A., Tarek, A., Lopez-Nores, M., GonzaLEZ-Sourtelo, S., Bassani, M., Antoniou, A., Gil-Solla, A., Ramos-Cabrer, M. \& Pazos-Arias, J. (2019). A Mobile App to Learn About Cultural and Historical Associations in a Closed Loop with Humanities Experts. Applied Sciences, 9(1), 9. https://doi. org/10.3390/app9010009 
Dervin, F., Paatela, M., Kuoppala, K., \& Riitaoja, A. L. (2012). Multicultural education in Finland: Renewed intercultural competences to the rescue? International Journal of Multicultural Education, 14(3). DOI: http://dx.doi.org/10.18251/ijme.v14i3.564

Dominguez, M. C. (2006). Investigacion y formacion del profesorado en una sociedad intercultural (Research and teacher training in an intercultural society). Universitas.

Dominguez, M. C. (2015). La formacion de profesores y educadores (Teacher training). En A. Medina (dir.), Didactica general: formacion basica para los profesionales de la educacion (General didactics: basic training for education professionals) (pp. 449-488). Universitas.

Dominguez, M. C., Levi, G., Medina, A. \& Mendez, R. M. (2012). Armonizacion de competencias entre la educacion secundaria y la universidad (Harmonization of competencies between secondary education and university). Revista Riaices, 5-13.

Dominguez, M. C., Medina, A., \& Lopez, E. (2018). Desarrollo de competencias en el primer curso de universidad: estudio de caso (Competences Development during the First Year at University: A Case Study). Publicaciones, 48(1), 47-62. https://revistaseug.ugr.es/index.php/publicaciones/ article/view/7325/6412

Dominguez, M.C. Medina, M.d.C, Gonzalez-Fernandez, R. \& Lopez-Gomez, L. (2019). Metodologia de investigacion para la educacion y la diversidad (Research methodology for education and diversity). UNED.

Dominguez, M. C., Medina, M. d C. \& Medina, A. (2017). Formacion del profesorado para el encuentro y dialogo entre culturas (Teacher training for the encounter and dialogue between cultures). En A. Medina, A. de la Herran \& M.C. Dominguez, Nuevas perspectivas en la formacion de los profesores (New perspectives in teacher training) (pp. 219-264). UNED.

Fernandez, M., \& Garrote, M. (2019). 'It's not my intercultural competence, it's me.'The intercultural identity of prospective foreign language teachers. Educar, 55(1), 0159-182.

Garrote, D., Arenas, J. A., \& Jimenez, S. (2018). Educacion intercultural en el aula: Profesorado y TIC (Intercultural education in the classroom: teachers and ICT). Prisma Social: Revista de Investigacion Social, 22, 326-345. URI: http://hdl.handle.net/10481/57829

Garrote, M. \& Fernandez, M. (2016). Intercultural competence in teaching: Defining the intercultural profile of student teachers. Bellaterra Journal of Teaching \& Learning Language \& Literature, 9(4), 41-58. DOI: $10.5565 / \mathrm{rev} / \mathrm{jtl} 3.670$

Gomes, C., Berry, M., Alzougool, B., \& Chang, S. (2014). Home away from home: International students and their identity-based social networks in Australia. Journal of International Students, 4(1), 2-15.

Gomez-Zermeno, M. G. (2009). Estudio exploratorio-descriptivo de competencias interculturales en instructores comunitarios del Consejo Nacional de Fomento Educativo que brindan servicio en la modalidad de atencion educativa a poblacion indigena del estado de Chiapas (Exploratory-descriptive study of intercultural competencies in community instructors of the National Council for Educational Development who provide educational services to the indigenous population of the state of Chiapas) (Tesis de doctorado, Tecnologico de Monterrey, Mexico). https://repositorio.itesm.mx/ ortec/handle/11285/572500

Hiller, G. G. \& Woźniak, M. (2009). Developing an intercultural competence programme at an international cross- border university. Intercultural Education, 20(sup1), S113-S124. https://doi. org/10.1080/14675980903371019

Huber, G. (2014). Investigacion en la comunicacion didactica (Research in didactic communication). En A. Medina, M.C. Dominguez \& A. de la Herran (coords.), Las Fronteras de la Investigacion Didactica (Frontiers of didactic research), (pp. 73-114). UNED.

Krathwohl, D. R., Bloom, B. S., \&Bertram, B. M. (1973).Taxonomy of Educational Objectives, the Classification of Educational Goals. Handbook II: Affective Domain. David McKay Co., Inc

Llinas, H. (2006). Estadistica Inferencial (Inferential Statistics).Ediciones Uninorte. 
Medina, A., Dominguez, M. C., \& Medina, C. (2010). Las nuevas escuelas y docentes (New schools and teachers). En J. Saio (coord.), Tendiendo puentes hacia la interculturalidad (Building bridges to interculturality) (pp. 19-50). K \& L.

Medina, A., Ruiz, A., Perez, E., \& Dominguez, M. C. (2019). Diagnostico de un programa de formacion de docentes en competencias para el primer ano de universidad (Diagnosis of a teacher training programme in competencies for the first year of university). Aula abierta, 48(2), 239-250. https:// doi.org/10.17811/rifie.48.2.2019.239-250

Moreira, R., Carlini, R., Lopes, R.C. \& Rocha Soares, R. (2019). Diversidade na formacão de professores de musica: o caso do tambor de crioula no Maranhão (Diversity in music teacher training: the case of the Creole drum in Maranhão). OPUS, 25(1), 183-199. DOI 10.20504/opus2019a2508

Moreno, A., De la Torre, M., \& Vermeulen, A. (2016). Diseno y evaluacion de VISP, una aplicacion movil para la practica de la competencia oral (VISP design and evaluation, a mobile application to practise oral competence). Revista Iberoamericana de Educacion a Distancia, 19(1), 63-81. doi: http:// dx.doi.org/10.5944/ried.19.1.14580

Navarro, V., Ricardo, C., Astorga, C., Cano, J., y Escalante, E. (2018). Formacion y desarrollo de competencias TIC e intercultural de educadores infantiles para la convivencia escolar. Revista de Paz y Conflictos, 11(1), 181-208. DOI: 10.30827/revpaz.v11i1.6490

Quintriqueo, S., Sanhueza, S. \& Friz, M. (2017). Triangulacion de metodos como propuesta para el estudio de competencia comunicativa intercultural en contextos de inmigracion e interculturalidad (Triangulation as proposed research method for the study on intercultural communicative competence in the context of school migration and interculturality). Andamios, 14(34), 283-303. DOI: $10.29092 /$ uacm.v14i34.590

Ricardo-Barreto, C., et al. (2020). Trends in using ICT resources by professors in HEIs (Higher Education Institutions). Journal of Information Technology Education: Research, 19 (395-425). https://doi. org/10.28945/4601

Ricardo, C. \& Cano, J. (2018). Diseno de actividades de aprendizaje virtuales para favorecer el desarrollo de la competencia intercultural del profesorado (Design of virtual learning activities to promote the development of teachers' intercvultural competence). En: F. Del Pozo (Comp.), Pedagogia Social en Iberoamerica: Fundamentos, ambitos y retos para la accion educativa (Social Pedagogy in Latin America: Foundations, scope and challenges for educational action) (pp.217-236). Editorial Universidad del Norte

Ricardo, C. (2017). Ambientes virtuales de aprendizaje: Retos para la formacion y el dialogo intercultural (Learning virtual environments: A challenge for intercultural training and dialogue). Editorial Universidad del Norte.

Ricardo, C. T., Llinas, H. \& Hernandez, S. (2017). Competencias interculturales de profesores virtuales en universidades de la Costa Caribe Colombiana (Appropiation's level of intercultural competences from on-line teachers in Colombian Caribbean Coast's Universities). Revista Opcion, 33(82), 263-279. https://produccioncientificaluz.org/index.php/opcion/article/view/22846/22768

Ricardo, C. T., \& Medina Rivilla, A. (2013). Actitudes y creencias de la competencia intercultural en profesores virtuales (Attitudes and beliefs of intercultural competence in online teachers). Revista Cientifica Ingenieria y Desarrollo, 31(2), 272-290. http://www.scielo.org.co/pdf/inde/v31n2/ v31n2a06.pdf

Rodriguez-Garcia, A., Hinojo, F. \& Agreda, M. (2019). Diseno e implementacion de una experiencia para trabajar la interculturalidad en Educacion Infantil a traves de realidad aumentada y codigos QR (Design and implementation of an educational project on interculturality in early childhood education using augmented reality and QR codes). Educar, 55(1), 59-77. DOI: https://doi. org/10.5565/rev/educar.966

Rodriguez-Izquierdo, R. M. (2015). Las TIC como ecosistema para la construccion de la competencia intercultural (ICT as ecosystem for the construction of intercultural competence). Profesorado, 19(1), 368-388. http://www.ugr.es/local/recfpro/rev191COL2.pdf 
R Team. (2020). Function chisq.test. In R stats package, version, 1.3.0. Retrieved from https://www. rdocumentation.org/packages/stats/versions/3.6.2/topics/chisq.test

Ruf, U. \& Gallin, P. (1998). El intercambio entre diversos. Los principios de una didactica interactiva y transdiciplinear (The exchange between diverse. The principles of an interactive and transdiciplinary didactics). Seelze-Velber: Kallmeyersche Verlagsbuchhandlung. https://www.metaaccion.com/ images/pdf/583366f5e681a-practico_17_earth_metaaccion_aa_en_grupos_aprendizaje_por_ dialogo_huber.pdf

Thapa, S. (2019). Assessing Intercultural Competence in Teacher Education: A Missing Link. In H. Westerlund, S. Karlsen \& H. Partti (eds.), Visions for Intercultural Music Teacher Education, (pp. 163-176). https://doi.org/10.1007/978-3-030-21029-8_11

Yilmaz, F. (2016). Multiculturalism and multicultural education: A case study of teacher candidates' perceptions. Cogent Education, 3(1). https://doi.org/10.1080/2331186X.2016.1172394

Valverde, A. (2010) La formacion docente para una educacion intercultural en la escuela secundaria (Teacher training for intercultural education in secondary schools).Cuicuilco, 17(48), 133-174. http://www. scielo.org. mx/pdf/cuicui/v17n48/v17n48a8.pdf

Vogt, K. (2016). Teaching practice abroad for developing intercultural competence in foreign language teachers. Canadian Journal of Applied Linguistics/Revue canadienne de linguistique appliquee, 19(2), 85-106. https://journals.lib.unb.ca/index.php/CJAL/article/view/24229

Wang, M., Yang, L.-Z., \& Chen, T. (2020). The effectiveness of ICT-enhanced learning on raising intercultural competencies and class interaction in a hospitality course. Interactive Learning Environments, 1-13. https://doi.org/10.1080/10494820.2020.1815223

Wickham, H. (2019). Package tidyverse, version, 1.3.0. https://cran.r-project.org/web/packages/tidyverse/ tidyverse.pdf 